\title{
The role of root buds in the regeneration of Casearia sylvestris Swartz (Salicaceae) in the Cerrado, São Carlos, São Paulo State, Brazil
}

\author{
Maristela Imatomi ${ }^{1,3}$, João Paulo Souza ${ }^{2}$, Sonia Cristina Juliano Gualtieri ${ }^{1}$ and Alfredo Gui Ferreira ${ }^{1}$
}

Received: 25.09.2012; accepted: 31.01.2014

\begin{abstract}
The role of root buds in the regeneration of Casearia sylvestris Swartz (Salicaceae) in the Cerrado, São Carlos, São Paulo State, Brazil). The present work describes the fire effects on the population structure of Casearia sylvestris Swartz (Salicaceae). Diameter and height structure as well as spatial distribution patterns of the root sprouts were analyzed pre- and post-fire. The morphology and anatomy of the underground system were also analyzed in order to investigate the nature and origin of sprouts from this system. In this study, a 10-ha of Cerrado area was sampled from February to November 2006; in August, a fire burned roughly $80 \%$ of the study area, allowing us to compare the data collected pre- and post-fire. Our findings show that the underground systems consisted of specialized roots and buds originated close to the vascular cambium. The spatial distribution of the root sprouts became clustered pre- and post-fire and most of the root sprouts were concentrated in the first size class, indicating that the sprouts from roots play an important role in the recovery of this species in burnt areas. Keywords: Cerrado, natural fires, sprouting, vegetative reproduction
\end{abstract}

RESUMO - (A função de raízes gemíferas na regeneração de Casearia sylvestris Swartz (Salicaceae) no Cerrado, São Carlos, SP, Brasil). Este artigo descreve os efeitos de incêndio na estrutura populacional de Casearia sylvestris Swartz (Salicaceae). Foram analisados a estrutura de diâmetro e altura e o padrão de distribuição espacial antes e após o fogo. Além disso, foi realizada a caracterização morfológica e anatômica do sistema subterrâneo para determinar a natureza e origem dos brotos oriundos desse sistema. Neste estudo foram amostrados 10 ha de fevereiro a novembro de 2006, em agosto, um incêndio queimou cerca de $80 \%$ da área de estudo, permitindo a comparação de dados coletados antes e após este evento. Foram verificados que os sistemas subterrâneos gemíferos são de natureza radicular e que os brotos se originam próximo ao câmbio vascular. A distribuição espacial dos brotos de raiz tornou-se agregada após o incêndio e houve maior concentração de brotos de raiz na primeira classe de tamanho indicando que esses brotos são responsáveis pela recomposição dessa espécie em áreas queimadas.

Palavras-chave: brotamento, Cerrado, incêndios naturais, reprodução vegetativa

\section{Introduction}

The Cerrado is the second most extensive phytogeographical domain in Brazil, occupying 21\% of the land area, and it is considered the last agricultural frontier in the world (Borlaug 2002). Cerrado regions contain a mosaic of vegetation types, among which the savanna physiognomy prevails $(67 \%$ of the total area), constituting the Cerrado strictu sensu (Coutinho 2006). The main abiotic determinants of the Cerrado are weathered, nutrient-poor acidic soils, markedly summer-wet periods and cooler temperatures, dry winters and recurring natural fires (Klink \& Machado
2005, Haridasan 2008). Tree species in the Cerrado exhibit morphological and physiological adaptations to the periodic disturbances. Such adaptations include functionally herbaceous or woody geoxylic suffrutices with enlarged underground xylopodia or lignotubers, thick corky bark, pachycaul rosette-forming shrubs and trees with sparse branching, thick shoots and leaves concentrated at shoot tips, perennial herbs, and specialized flowering and fruiting phenologies (Simon et al. 2009). Plants subjected to water stress decrease their transpiration and thus their net photosynthesis (Prado et al. 2004).

1. Universidade Federal de São Carlos, Departamento de Botânica, Rodovia Washington Luís SP-310, Km 235, 13565-905 São Carlos, SP, Brasil

2. Universidade Federal de Viçosa, Campus Florestal, Rodovia LMG 818, km 6, 35690-00 Florestal, MG, Brasil

3. Corresponding author: maristelaimatomi@yahoo.com.br 
Cerrado fire events occur naturally during the wet season and are normally patchy, of low intensity and frequently self-extinguish rapidly (Miranda et al. 1993). On the other hand, when fire events occur on the dry season, often caused by human activity, the flames spread through a large amount of dry herbaceus layer, which fuels an intense fire (Miranda et al. 2002). The highest temperatures occur $60 \mathrm{~cm}$ above ground and range from 85 to $840{ }^{\circ} \mathrm{C}$ (Miranda et al. 1993, 1996). Such fires damage shoots and leaves (mainly by the flow of hot air during the fire) or the whole individual plants. Soil temperature is around $50{ }^{\circ} \mathrm{C}$, decreasing exponentially with depth and becoming negligible at and below a depth of $5 \mathrm{~cm}$; therefore such insignificant soil temperature alterations are unlikely to have any direct effect on soil organic matter, microbial population, buried seeds (Mistry 1998) or the underground vegetative system.

The impact of fire affects a wide range of vital rates, including survival, growth, sexual reproduction and seedling establishment. Underground systems are protected in the soil, in a way that sprouting from an underground bud system, in the Cerrado post-fire, is a good ecological strategy (Hoffmann \& Moreira 2002). According to Jeník (1994), vegetative reproduction of woody plants falls into three categories: the capacity of aerial branch reiteration (epicormic shoots), sprouting of basal portions of trunk (coppice shoots), and sprouting from root buds (root suckers or root sprouts). Root suckers (new stems originating from root buds at some distance from the main trunk) are much larger than seedlings and they should have a greater ability to survive throughout fire events (Hoffmann 1999). Thus, in the Cerrado, root buds may increase the population density by the production of root suckers which may lead to the recovery of burnt areas.

The occurrence of buds on the roots and the accumulation of energy reserves in such roots play a remarkably important role of adaptation for the survival of plants in the Cerrado (Rizzini 1997, Hayashi \& Appezzato-da-Glória 2005). Root sprouting is associated with environmental disturbance and promotes structural changes in plant populations (Bellingham \& Sparrow 2000, Hoffmann \& Moreira 2002); it also alters the reproductive patterns of the clonal populations and decreases genetic diversity (Handel 1985), changing the balance between sexual and asexual reproduction (Hoffmann 1998).

A few studies have reported how fire affects the way in which woody species become established in the
Cerrado. However, studies showed that fire events tend to increase the importance of vegetative reproduction in comparison to sexual reproduction (Hoffmann 1998, Silva et al. 2009). Palermo \& Miranda (2012) observed that no flowers were produced by Qualea parviflora Mart. plants in the burned area, one year after a fire event, suggesting that this species may require more than a year to return to the normal reproductive cycle. As a matter of fact, the strategies of very few species have been investigated up to date; therefore additional studies regarding fire effects on the population structure of Cerrado species are quite essential to understand the behavior of such fire resistant species. In this study, the fire effects on the population structure of Casearia sylvestris Swartz (Salicaceae) were investigated. Our study was aimed at answering the following questions: $i$ ) What is the anatomical nature of the underground system from which sprouts arise? ii) Does the fire favor the production of shoots from such underground systems? iii) Does the fire change the diameter and height structure and spatial distribution pattern of Casearia sylvestris? To this end, the diameter and height structure and spatial distribution pattern were analyzed pre- and post-fire in the Cerrado. Furthermore, the morphology and anatomy of the underground system were characterized to investigate the nature and origin of sprouting.

\section{Material and methods}

Study area - Neotropical Cerrado in São Carlos, São Paulo State, Brazil (21 ${ }^{\circ} 58^{\prime}-22^{\circ} 00^{\prime}$ S and 47051'$\left.47^{\circ} 52^{\prime} \mathrm{W}\right)$. Plant material was collected from the study area and the population structure of Casearia sylvestris was analyzed accordingly. The specimen exsiccate was deposited in the Herbarium of the Universidade Federal de São Carlos (HUFSCar) under accession number 8372. The local meteorological station recorded that the average annual rainfall and air temperature from 1992 to 2010 were $1,361.6 \mathrm{~mm}$ and $21.5^{\circ} \mathrm{C}$, respectively. There are two well-defined seasons: a rainy season from October to March and a dry season from April to September (Monteiro \& Prado 2006). Throughout the study period - from February to November 2006 - the total rainfall was 1,223 mm and the mean air temperature was $21^{\circ} \mathrm{C}$. The topography of the area is gently rolling, at an average elevation of 850 m.a.s.1. The groundwater is at a depth of $10 \mathrm{~m}$ and the soil is classified as dystrophic latosol, nutrient-poor but rich in exchangeable aluminum (Kanno 1998). The 
vegetation is characterized by a woody layer formed by trees and bushes which protrude above a welldefined herbaceous layer (Ribeiro \& Walter 1998).

Plant material - In the Cerrado, Casearia sylvestris Swartz. is a semi-deciduous tree reaching an average height of $164 \mathrm{~cm}$ (Souza et al. 2009). It occurs from Mexico to Argentina, with morphological variations in response to different habitats (Carvalho 2007). It is a common and widely distributed tree species in the Cerrado and forest areas (Ratter et al. 2003). Pharmacological importance is related to its antiulcer, anti-inflammatory, anti-snake venom and antitumor activity (Ferreira et al. 2011). Its wood is used as a fuel and is suitable to build fences, posts, stakes, rustic carpentry and tool handles (Torres \& Yamamoto 1986).

Morpho-anatomy of the underground system - Root cuttings with sprouts of Casearia sylvestris were fixed in Randolph's CRAF (chromium-acetic-formalin), dehydrated in an ethanol series (Johansen 1940) and imbedded in paraffin. Transverse sections were cut from the blocks with a rotary microtome at a thickness of 10-12 $\mu \mathrm{m}$. The sections were affixed with Bissing's adhesive (Bissing 1974). For permanent staining, the sections were deparaffinized in xylene and rehydrated in a decreasing ethanol series. Next, they were placed sequentially in $1 \%$ tannic acid, $3 \%$ iron chloride (Pizzolato 1977), 1\% safranin and 2\% astra blue (Gerlach 1969). The permanent sections were mounted with Apathy's syrup (sucrose and gum arabic) (Richards 1943). Histochemical tests were carried out by using macerated and fixed material or cross sections stained with Lugol's iodine, for the starch detection (Kraus \& Arduin 1997). Photomicrographs of the material were taken with an Olympus PM-C35DX camera attached to an Olympus BX-41 optical microscope with micrometric scales being photographed and enlarged under the same optical conditions.

Population structure - Diameter and height structure and spatial distribution patterns of root sprouts of Casearia sylvestris were determined by the transect method. Two transects were systematically placed in 10 ha of the fire area in the Cerrado. These transects were $50 \mathrm{~m}$ long by $10 \mathrm{~m}$ wide, extending from a firebreak in a perpendicular position and $20 \mathrm{~m}$ apart. Plant individuals which sprouted from root buds and their sucker shoots were sampled along these transects. Sampling was done from February to November 2006.
In August, an accidental fire burned roughly $80 \%$ of the study area, allowing data collected pre- and postfire to be compared (sampling restarted in September). Such area had not been burned for approximately six years, during which much dry biomass had accumulated (Silva et al. 2009).

The underground systems were exposed with the aid of a hand-hoe in order to identify the main trunks and sprouts. Main trunks refer to plants growing from seeds, with an axial root (figure 1a), whereas the term root sprout or sucker designates an individual originating from a root bud (figure 1b). A tape measure and digital caliper were used to measure the total height above the soil and stem base diameter (SBD) of the root sprouts and main trunks as well as the distance between the two.

Mathematical and statistical data analysis - Population structure data for Casearia sylvestris were plotted on graphs based upon the distribution of height and stem base diameter. These variables were divided into size classes by using the equation: $\mathrm{A} \mathrm{k}^{-1}$, in which $\mathrm{A}$ is the difference between the largest and smallest values and $\mathrm{k}$ is the number of classes, defined by Sturges' formula $\mathrm{k}=1+3.3 \log _{10} \mathrm{n}$, with $\mathrm{n}$ being the total number of individuals sampled.

Spatial distribution was analyzed by computing two indices: 1) Dispersion Index (DI), given by the formula $\mathrm{DI}=\mathrm{S}^{2} \mathrm{M}^{-1}$, in which $\mathrm{S}^{2}$ is the variance of the number of individuals, and $\mathrm{M}$ is the mean number of root sprouts); 2) Morisita Index ( $\left.\mathrm{I}_{\mathrm{M}}\right)$, given by the formula $I_{M}=q \sum n(n-1)$. $[N(N-1)]^{-1}$, with $q$ being the total number of plots sampled, $\mathrm{n}$ being the number of individuals in the $i$ plot and $\mathrm{N}$ being the total number of root sprouts sampled $(\mathrm{N}=57$ pre- and $\mathrm{N}=34$ post-fire). According to Brower \& Zar (1984), DI can be influenced by the size of the population and plots, while $I_{M}$ does not have this characteristic, not being affected by the random removal of population members. The spatial pattern is considered to be random when DI and $\mathrm{I}_{\mathrm{M}}=1$; uniform if DI and $\mathrm{I}_{\mathrm{M}}<1$ and clustered if DI and $\mathrm{I}_{\mathrm{M}}>1$. Statistical significance of the differences between DI or $\mathrm{I}_{M}$ and one was tested by the chi-squared $\left(\chi^{2}\right)$ test, for non-normal data (Brower \& Zar 1984). All the statistical tests were run in the statistical BioEstat 3.0 package (Sociedade Civil Mamirauá, $\mathrm{CNPq}$ ).

\section{Results and Discussion}

The roots showed a secondary plant body, with a periderm, below which was the cortical parenchyma 
containing ducts, in direct contact with the secondary phloem. The secondary xylem showed solitary or multiple vessels and starch grains accumulated in the parenchymatic ray cells of the secondary vascular tissues as well as in the cortex. Furthermore, there was a primary xylem with centripetal maturation in the central region of Casearia sylvestris underground system, which corroborates that this organ was rootbased (figure 2a).

Morpho-anatomical studies of the underground systems of plants from the Cerrado have shown the presence of gemmiferous underground systems, such as xylopodia and root buds (Hayashi \& Appezzatoda-Gloria 2005, Vilhalva \& Appezzato-da-Gloria 2006). Alonso \& Machado (2007) described the morpho-anatomy and sprouting ability of the underground system of Erythroxylum species in the Cerrado. They found that sub-shrubby species occurred in clumps and had underground systems interlinked by soboles in Erythroxylum nanum and by xylopodia in E. campestre, while the shrubby species E. tortuosum grew isolated and highly branched with an underground system consisting of a primary root system near the soil surface. The authors concluded that the abundance of reserves and the bud-forming potential of the soboles, xylopodia and roots resulted in the production of vigorous branches, showing great value in the regeneration of the aerial biomass post-fire or seasonal drought in the Cerrado.

Above-ground biomass is eliminated post-fire, so that plants lose their photosynthetic capacity. In order to support respiratory demands and initiate sprouting, such plants shall have sufficient carbohydrates and nutrients stored in their underground organs (Bowen \& Pate 1993). Moreira et al. (2012) while

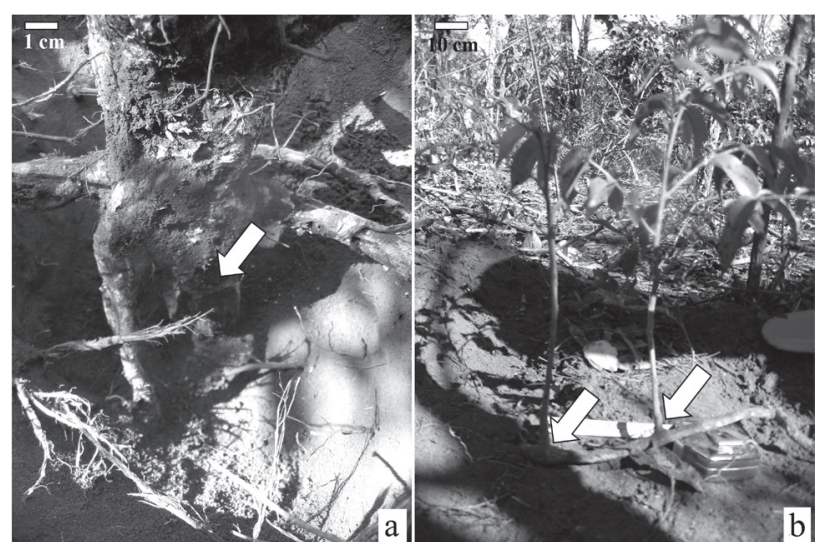

Figure 1. a. Main trunk of Casearia sylvestris Swartz (Salicaceae) with primary root (arrow). b. sprouts (arrows) from root buds of Casearia sylvestris. studying factors driving intraspecific variability in sprouting, found that resources stored by the plant pre-disturbance can boost its initial ability to sprout and the sprouting vigor and, consequently, its initial post-disturbance ability to acquire new resources. Likewise, the development of root buds depends on the resources stored by the main trunk. The present study showed that $C$. sylvestris root has starch grains which augment its ability to produce sprouts.

Casearia sylvestris root sprouts developed near the vascular cambium, which formed a ray of more dilated parenchyma internally (figure $2 b$ ). Hayashi \& Appezzato-da-Glória (2009) observed various ways in which buds formed on planted root cuttings: close to the vascular cambium in Centrolobium tomentosum, from the callus in Bauhinia forficata and Esenbeckia febrifuga and by proliferation of the phloematic parenchyma in Inga laurina.

Based on the population under study, it was observed that vegetative reproduction prevailed over sexual reproduction in both pre- and post-fire (table 1). The spatial distribution of the C. sylvestris sprouts from roots pre-fire was in a random pattern, becoming clustered post-fire, according to both

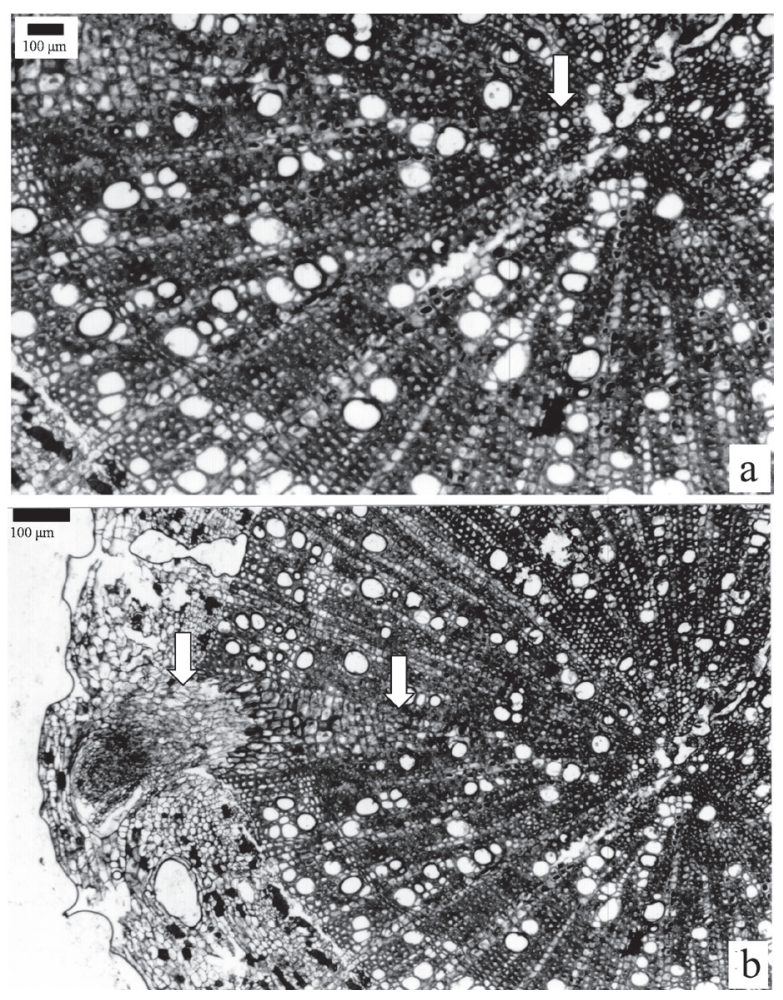

Figure 2. Microscopic image of transverse sections of root cuttings of Casearia sylvestris Swartz Swartz (Salicaceae). a. central region of the root with external metaxylem (arrows) and internal protoxylem (arrows). b. buds (arrows) forming in the root. 
indices used (table 1). Sprouting from root buds could represent an effective strategy of spatial reoccupation and vegetative propagation; moreover, sprout shoots have the potential to emerge at variable distances from the main trunk and become independent plants (Rodrigues et al. 2004). Imatomi et al. (2009) reported that $C$. sylvestris seeds exhibit a low germination rate under laboratory conditions, whereas the presence of root buds may explain the wide distribution and high population density of this species. Furthermore, the potential of these buds for vegetative reproduction would enable the use of root cuttings to restore degraded areas. Hayashi \& Appezzato-da-Glória (2009) demonstrated the ability of Bauhinia forficata, Centrolobium tomentosum, Inga laurina and Esenbeckia febrifuga roots to produce sprouts when they were cut into sections and isolated from the original plant.

Few studies of the spatial distribution of tree species in the Cerrado have found a clustered pattern (Hay et al. 2000, Souza \& Coimbra 2005). The patterns of spatial distribution can be affected by biotic factors: vegetative propagation, seed dispersal, intra and interspecific interactions and varied development stages, and abiotic ones: light, temperature, soil, moisture, nutrients and environmental disturbances (such as fire, Melo et al. 2004). Hence, a particular pattern can result from one factor or the interaction of many (Grau \& Veblen 2000). In our study, the spatial distribution pattern of $C$. sylvestris changed from random to clustered in response to the fire in the area. Some studies have shown that fire events damage plant aerial parts, causing a reduction in the amount of auxin reaching the roots, which in turn stimulates the development of sprouts (Bosela \& Ewers 1997, Hoffmann \& Moreira 2002, Rodrigues et al. 2004). The sprouts from the roots may then lead to a clustered pattern, since the mean distance between a main trunk and its sprouts depends on the energy cost of root production and the presence of spots favorable to their growth (Hutchings 1997).

The fire affected the diameter and height distribution of main trunks of $C$. sylvestris (figure 3 $\mathrm{c}, \mathrm{d}, \mathrm{g}$ and $\mathrm{h}$ ). Prior to the fire, most individuals were concentrated in the intermediate classes of diameter and height (figure $3 \mathrm{c}$ and $\mathrm{d}$ ), while post-fire, the main trunks were concentrated in the larger size classes, indicating mortality of smaller individuals (figure $3 \mathrm{~g}$ and $\mathrm{h}$ ). The diameter and height of $C$. sylvestris root sprouts were unaffected by the fire, and the largest concentration of sprouts pre- and post-fire were in the first size class (figure $3 a, b$, e and f). The concentration of individuals in intermediate height classes, as found in the $C$. sylvestris main trunks, indicates reduction in recruitment and reproduction by seeds, although some individuals are reproductively mature and potentially able to maintain the stock of seeds in the area. According to Little \& Wadsworth (1964), under good conditions $C$. sylvestris is capable of flowering and fruiting in the second year of life, when it reaches about $1 \mathrm{~m}$ height. Imatomi et al. (2009) observed that $77.8 \%$ of $C$. sylvestris seeds were subjected to predation or aborted (unviable) and only $20 \%$ of the viable seeds sown in a greenhouse emerged. On the other hand, young root sprouts ensure the maintenance of the population, likely due to greater resistance to physical damage by root sprouts than by seedlings (Toivonen et al. 2011) and to rapid development, because their resources are drawn from the main trunk which is already established.

Environmental disturbances interfere in the reproductive strategy of plants by reducing the rate of reproduction by seeds and stimulating the formation and development of root buds (Kauffman 1991). Root sprouts grow rapidly as they are partly nourished by the root system of the main trunks. Seedlings require more time to become established since they are more exposed to adverse conditions (Kauffman 1991).

Table 1. Parameters of population structure of Casearia sylvestris Swartz (Salicaceae) plants in a Cerrado area (São Carlos, São Paulo State, Brazil) pre- and post-fire event.

\begin{tabular}{lcc}
\hline & Before fire & After fire \\
\hline Percentage of individuals with sprouts (\%) & 20 & 80 \\
Number of sprouts per individual & 3.6 & 10.2 \\
Percentage of root sprouts (\%) & 78.26 & 91.1 \\
Distance between sprouts and tree (cm) & $11-172$ & $29-177$ \\
Morisita index ( $\left.\mathrm{I}_{\mathrm{M}}\right)$ & 0.31 & 5.39 \\
Dispersion index (DI) & 0.86 & 1.94 \\
\hline
\end{tabular}




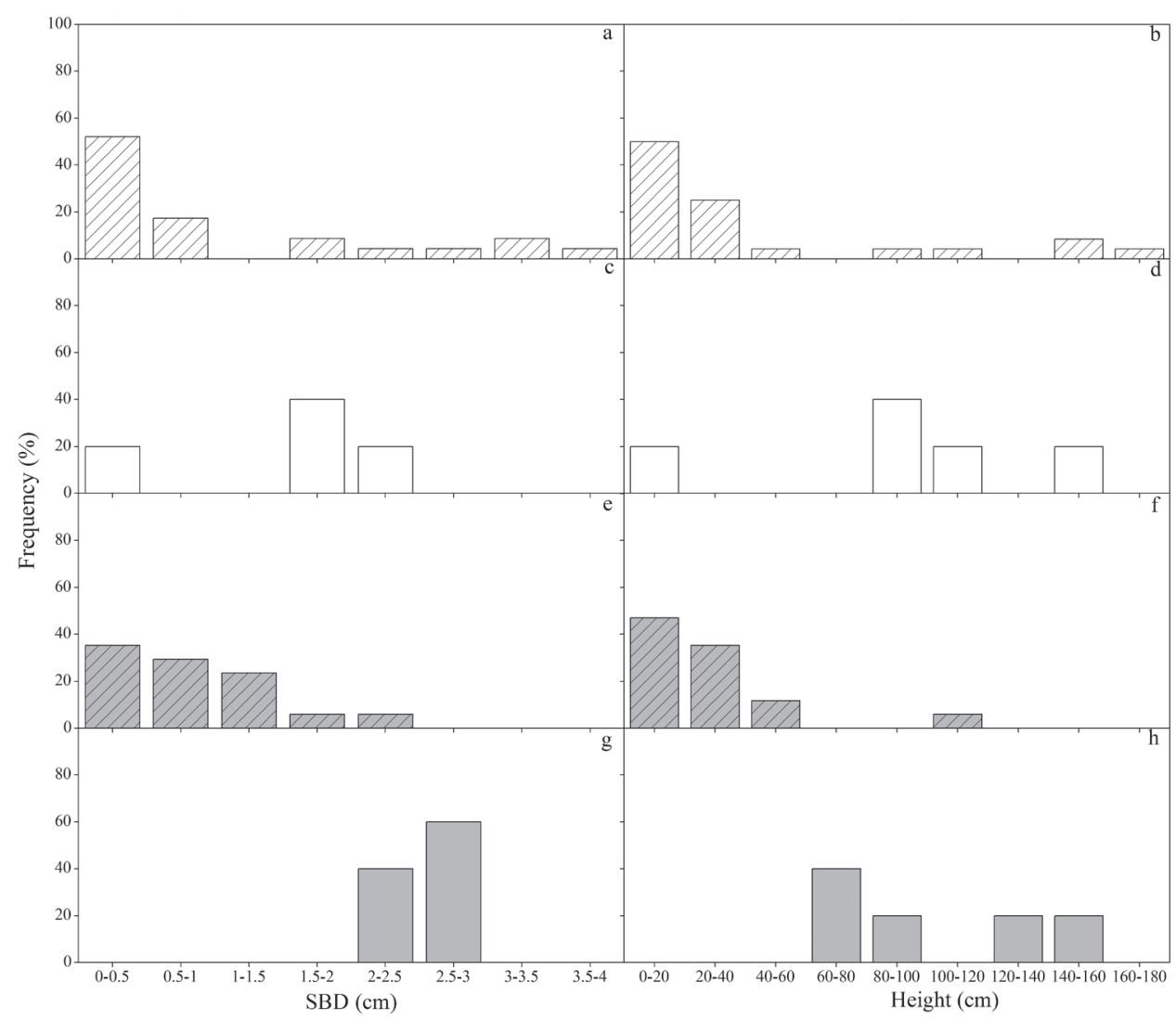

Figure 3. Distribution of stem base diameter (SBD) and height classes of Casearia sylvestris Swartz (Salicaceae) root sprouts and main trunks in a Cerrado area of the Universidade Federal de São Carlos (São Carlos, São Paulo State, Brazil), before and approximately one

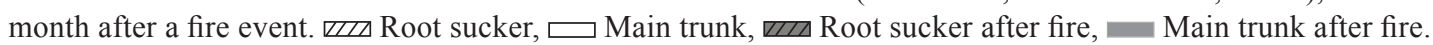

Therefore, environmental disturbances, particularly fire, can promote the growth of these root sprouts, offsetting the negative effect of the mortality of seedlings (Hoffmann 1999). Based on the population under study, the prevailing reproductive strategy was vegetative, $85 \%$ of the plants analyzed arising from root buds. Sprouting from roots is an important natural mechanism for regeneration just after a natural disturbance, because it quickly provides new plant cover in affected areas (Paciorek et al. 2000, Kennard et al. 2002).

Cerrado species have become adapted to fire events during evolution. Some plant species need fire events to flower, germinate or disperse seeds. Most Cerrado woody species, shoots and trunks show suberization, promoting insulation of internal tissues (Gottsberger \& Silberbauer-Gottsberger 2006). An increase in vegetative reproduction (from root sprouts) with increasing fire frequency is one of several interactive adaptations of Cerrado woody species in response to disturbance. The present study has shown that the underground systems of C. sylvestris have the characteristics of root and sprouts originated close to the vascular cambium. The spatial distribution of the root sprouts became clustered postfire and root sprouts were concentrated in the first size class, indicating that these sprouts play a major role in the recovery of this species in burned areas. Therefore, fire events favor the production of shoots from the underground systems. Furthermore, root sprouts are an important morpho-anatomical adaptation in the Cerrado, as they allow prompt colonization of burnt areas.

\section{Acknowledgments}

The authors with to thank CNPq, for their financial support and scholarships awarded to the authors. We also would like to thank Professor Marcos Arduin from the Botany Department (UFSCar), for assisting us with morpho-anatomical characterization.

\section{Literature cited}

Alonso, A.A. \& Machado, S.R. 2007. Morphological and developmental investigations of the underground system of Erythroxylum species from Brazilian Cerrado. Australian Journal of Botany 5: 749-758. 
Bellingham, P.J. \& Sparrow, A.D. 2000. Resprouting as a life history strategy in woody plant communities. Oikos 89: 409-416.

Bissing, D.R. 1974. Haupt's gelatin adhesive mixed with formalin for affixing paraffin sections to slides. Stain Technology 49: 116-117.

Borlaug, N.E. 2002. Feeding a world of 10 billion people: the miracle ahead. In vitro Cellular and Developmental Biology-Plant 38: 221-228.

Bosela, M.J. \& Ewers, F.W. 1997. The mode of origin of root buds and root sprouts in the clonal tree Sassafras albidum (Lauraceae). American Journal of Botany 84: 1466-1481.

Bowen, B.J. \& Pate, J. S. 1993. The significance of root starch in post-fire shoot recovery of the resprouter Stirlingia latifolia R.Br. (Proteaceae). Annals of Botany 72: 7-16.

Brower, J.E. \& Zar, J.H. 1984. Field and laboratory methods for general ecology. Wm.C. Brown Publishers, Dubuque.

Carvalho, P.E.R. 2007. Cafezeiro-do-mato - Casearia sylvestris. Circular Técnica138. Embrapa, Brasília.

Coutinho, L.M. 2006. O conceito de bioma. Acta Botanica Brasilica 20: 13-23.

Ferreira, P.M.P., Costa-Lotufo, L.V., Moraes, M.O., Barros, F.W.A., Martins, A.M.A., Cavalheiro, A.J., Bolzani, V.S., Santos, A.G. \& Pessoa, C. 2011. Folk uses and pharmacological properties of Casearia sylvestris: a medicinal review. Anais da Academia Brasileira de Ciências 83: 1373-1384.

Gerlach, D. 1969. Botanische Mikrotechnik: eine Einführung. Georg Thieme, Stuttgart.

Gottsberger, G. \& Silberbauer-Gottsberger, I. 2006. Life in the Cerrado: a South American tropical seasonal vegetation: Origin, structure, dynamics and plant use, v. 1. Reta Verlag, Ulm.

Grau, R.H. \& Veblen, T.T. 2000. Rainfall variability, fire and vegetation dynamics in neotropical montane ecosystems in north-western Argentina. Journal of Biogeography 27: 1107-1121.

Handel, S.N. 1985. The intrusion of clonal growth patterns on plant breeding systems. The American Naturalist 125: 367-384.

Haridasan, M. 2008. Nutritional adaptations of native plants of the Cerrado biome in acid soils. Brazilian Journal of Plant Physiology 20: 183-195.

Hay, J.D., Bizerril, M.X., Calouro, A.M., Costa, E.M.N., Ferreira, A.A., Gastal, M.L.A., Goes Junior, C.D., Manzan, D.J., Martins, C.R., Monteiro, J.M.G., Oliveira, S.A., Rodrigues, M.C.M., Seyffarth, J.A.S. \& Walter, B.M.T. 2000. Comparação do padrão da distribuição espacial em escalas diferentes de espécies nativas do Cerrado, em Brasília, DF. Revista Brasileira de Botânica 23: 341-347.
Hayashi, A.H. \& Appezzato-da-Glória, B. 2005. The origin and anatomy of rhizophores in Vernonia herbacea and $V$. platensis (Asteraceae) from the Brazilian Cerrado. Australian Journal of Botany 53: 273-279.

Hayashi, A.H. \& Appezzato-da-Glória, B. 2009. Resprouting from roots in four Brazilian tree species. Revista de Biologia Tropical 57: 789-800.

Hoffmann, W.A. \& Moreira, A.G. 2002. The role of fire in population dynamics of woody plants. In: P.S. Oliveira \& R.J. Marquis (eds.). The Cerrados of Brazil: Ecology and Natural History of a Neotropical Savanna. Columbia University Press, New York, pp. 159-177.

Hoffmann, W.A. 1998. Post-burn reproduction of woody plants in a neotropical savanna: the relative importance of sexual and vegetative reproduction. Journal of Applied Ecology 35: 422-433.

Hoffmann, W.A. 1999. Fire and population dynamics of woody plants in a neotropical savanna: matrix model projections. Ecology 80: 1354-1369.

Hutchings, M.J. 1997. The structure of plant populations. In: M.J. Crawley (ed.). Plant ecology. Blackwell Science, Oxford, pp. 325-358.

Imatomi, M., Perez, S.C.J.G.A. \& Ferreira, A.G. 2009. Caracterização e comportamento germinativo de sementes de Casearia sylvestris Swartz. (Salicaceae). Revista Brasileira de Sementes 31: 36-47.

Jeník, J. 1994. Clonal growth in woody plants: a review. Folia Geobotanica \& Phytotaxonomica 29: 291-306.

Johansen, D.A. 1940. Plant microtechnique. McGraw-Hill Book, New York.

Kanno, S.S. 1998. Estudo ecofisiológico de duas espécies nativas do Cerrado: Kielmeyera coriacea e Kielmeyera variabilis - A disponibilidade hídrica e sua relação com as trocas gasosas, o potencial hídrico foliar e a fenologia. Tese de Doutorado, Universidade Federal de São Carlos, São Carlos.

Kauffman, J.B. 1991. Survival by sprouting following fire in tropical forests of the eastern Amazon. Biotropica 23: 219-224.

Kennard, D.K., Gould, K., Putz, F.E., Fredericksen, T.S. \& Morales, F. 2002. Effect of disturbance intensity on regeneration mechanisms in a tropical dry forest. Forest Ecology and Management 162: 197-208.

Klink, C.A. \& Machado, R.B. 2005. Conservation of the Brazilian Cerrado. Conservation Biology 19: 707-713.

Kraus, J.E. \& Arduin, M. 1997. Manual básico de métodos em morfologia vegetal. Editora Universidade Rural, Rio de Janeiro.

Little, E.L., Wadsworth, F.L. 1964. Common trees of Puerto Rico and Virgin Islands. Department of Agriculture, Washington.

Melo, F.P.L., Aguiar-Neto, A.V., Simabukuro, E.A. \& Tabarelli, M. 2004. Recrutamento e estabelecimento de plântulas. In: A.G. Ferreira \& F. Borghetti (eds.). Germinação: do básico ao aplicado. Artmed, Porto Alegre, pp. 237-250. 
Miranda, A.C., Miranda, H.S., Dias, I.F.O. \& Dias, B.F.S. 1993. Soil and air temperatures during prescribed Cerrado fires in Central Brazil. Journal of Tropical Ecology 9: 313-320.

Miranda, A.C., Miranda, H.S., Grace, J., Lloyd, J., McIntyre, J., Meier, P., Riggan, P., Lockwood, R. \& Brass, J. 1996. Fluxes of CO, over a Cerrado sensu stricto in Central Brazil. In: J.H. Gash, C.A. Nobre, J.M. Roberts \& R.L. Victoria (eds.). Amazonian Deforestation and Climate. John Wiley and Sons, Chichester, pp. 353-363.

Miranda, H.S., Bustamante, M.M.C. \& Miranda, A.C. 2002. The Fire Factor. In: P.S. Oliveira \& R.J. Marquis (eds.). The Cerrados of Brazil: ecology and natural history of a neotropical savanna. Columbia University Press, New York, pp. 51-68.

Mistry, J. 1998. Fire in the Cerrado (savannas) of Brazil: an ecological review. Progress in Physical Geography 22: 425-448.

Monteiro, J.A.F. \& Prado, C.H.B.A. 2006. Apparent carboxylation efficiency and relative stomatal and mesophyll limitations of photosynthesis in an evergreen Cerrado species during water stress. Photosynthetica 44: 39-45.

Moreira, B., Tormo, J. \& Pausas, J.G. 2012. To resprout or not to resprout: factors driving intraspecific variability in resprouting. Oikos 121: 1577-1584.

Paciorek, C.J., Condit, R., Hubbell, S.P. \& Foster, R.B. 2000. The demographics of resprounting in tree and shrub species of a moist tropical forest. Journal of Ecology 88: 765-777.

Palermo, A.C. \& Miranda, H.S. 2012. Efeito do fogo na produção de frutos de Qualea parviflora MART. (Vochysiaceae) em Cerrado sensu stricto. Revista Árvore 36: 685-693.

Pizzolato, T.D. 1977. Staining of Tilia mucilages with Mayer's tannic acid-ferric chloride. Bulletin of the Torrey Botanical Club 104: 277-279.

Prado, C.H.B.A., Wenhui, Z., Cardoza Rojas, M.H. \& Souza, G.M. 2004. Seasonal leaf gas exchange and water potential in a woody Cerrado species community. Brazilian Journal Plant of Plant Physiology 16: 7-16.

Ratter, J.A., Bridgewater, S. \& Ribeiro, J.F. 2003. Analysis of the floristic composition of the Brazilian Cerrado vegetation. III: comparison of the woody vegetation of 376 areas. Edinburgh Journal of Botany 60: 57-109.
Ribeiro, J.F. \& Walter, B.M.T. 1998. Fitofisionomias do bioma Cerrado. In: S.M. Sano \& S.P. Almeida (eds.). Cerrado, Ambiente e Flora. EMBRAPA CPAC, Planaltina, pp. 87-167.

Richards, A.G. 1943. Apathy's gum syrup. Turtox News 21: 24 .

Rizzini, C.T. 1997. Tratado de fitogeografia do Brasil: aspectos ecológicos, sociológicos e florísticos. Âmbito Cultural, Rio de Janeiro.

Rodrigues, R.R., Torres, R.B., Matthes, L.A.F. \& Penha, A.S. 2004. Tree species sprouting from root buds in a semideciduous forest affected by fires. Brazilian Archives of Biology and Technology 47: 127-133.

Silva, I.A., Valenti, M.W. \& Silva-Matos, D.M. 2009. Fire effects on the population structure of Zanthoxylum rhoifolium Lam (Rutaceae) in a Brazilian savanna. Brazilian Journal of Biology 69: 813-818.

Simon, M.F., Grether, R., Queiroz, L.P., Skema, C., Pennington, R.T. \& Hughes, C.E. 2009. Recent assembly of the Cerrado, a neotropical plant diversity hotspot, by in situ evolution of adaptations to fire. Proceedings of the National Academy of the United States of America, 106: 20359-20364.

Souza, J.P. \& Coimbra, F.G. 2005. Estrutura populacional e distribuição espacial de Qualea parviflora Mart. em um Cerrado sensu stricto. Bioscience Journal 21: 65-70.

Souza, J.P., Prado, C.H.B.A., Damascos, M.A. \& Albino, A.L.S. 2009. Influence of shoot inclination on irradiance and morphophysiological leaf traits along shoots in Cerrado trees with distinct leaf deciduousness. Brazilian Journal of Plant Physiology 21: 281-289.

Toivonen, J.M., Kessler, M., Ruokolainen, K. \& Hertel, D. 2011. Accessibility predicts structural variation of Andean Polylepis forests. Biodiversity and Conservation 20: 1789-1802.

Torres, R.B. \& Yamamoto, K. 1986. Taxonomia das espécies de Casearia Jacq. (Flacourtiaceae) do estado de São Paulo. Revista Brasileira de Botânica 9: 239-258.

Vilhalva, D.A.A. \& Appezzato-da-Gloria, B. 2006. Morfo-anatomia do sistema subterrâneo de Calea verticillata (Klatt) Pruski e Isostigma megapotamicum (Spreng.) Sherff - Asteraceae. Revista Brasileira de Botânica 29: 39-47. 